\title{
Erratum to: Femtosecond pulse laser ablation of chromium: experimental results and two-temperature model simulations
}

\author{
M. Saghebfar ${ }^{1}$ M. K. Tehrani ${ }^{1}$ S. M. R. Darbani ${ }^{1}$ A. E. Majd ${ }^{2}$
}

Published online: 30 January 2017

(C) Springer-Verlag Berlin Heidelberg 2017

1 Erratum to: Appl. Phys. A (2017) 123:28

DOI 10.1007/s00339-016-0660-0

The original version of this article unfortunately contained a mistake in the text.

On page 6, right column, line 9 the unit was incorrect: $0.1121 \pm 0.02\left(\mathrm{~J} / \mathrm{m}^{2}\right)$ should read $0.1121 \pm 0.02\left(\mathrm{~J} / \mathrm{cm}^{2}\right)$.

The online version of the original article can be found under doi:10.1007/s00339-016-0660-0.

M. K. Tehrani

m_kavosh@mut-es.ac.ir

M. Saghebfar

saghebfar@mut-es.ac.ir

1 Optics-Laser Science and Technology Research Center, Malek Ashtar University of Technology, Isfahan, Iran

2 Electrical Engineering and Electronic Department, Malek Ashtar University of Technology, Tehran, Iran 